\title{
Pengembangan Sistem Reservasi Hotel Berbasis Mobile dengan Framework JQuery Mobile
}

\author{
Hotel Reservation System Development Based Mobile \\ with JQuery Mobile Framework
}

Gat

STMIK Pontianak

E-mail: gutsy0818@yahoo.com

\begin{abstract}
Abstrak
Banyaknya informasi yang dapat akses secara online dengan menggunakan mobile tidak terlepas dari banyaknya sistem yang dikembangkan oleh perusahaan dalam mendukung aktivitas bisnisnya. Perhotelan yang ada di Pontianak juga menyediakan berbagai fasilitas yang menarik dan juga menyediakan sistem pesan kamar online. Namun permasalahan yang terjadi ketika membuka halaman website yang dibuat tidak memperhatikan kapasitas dari perangkat mobile, menyebabkan ukuran layar tidak cocok sehingga banyak pengguna yang merasa tidak nyaman. Penelitian ini bertujuan menghasilkan informasi dan reservasi hotel yang dapat diakses dengan berbagai perangkat mobile terlepas dari ukuran perangkat mobile tersebut. Sistem yang telah dibangun memberikan manfaat dan keuntungan berarti karena JQuery Mobile memungkinkan sistem ini dapat berjalan diberbagai perangkat mobile. Adanya JQuery Mobile, para pengembang tidak perlu melakukan desain user interface dan pengkodean sistem dari awal karena JQuery Mobile memiliki framework yang siap dipergunakan dan dikembangkan sesuai dengan kebutuhan dari sebuah sistem. Perbaikan dan pengembangan perlu terus dilakukan untuk memastikan fleksibilitas sistem terhadap semua perangkat mobile terutama untuk ukuran layar yang kecil dan memiliki kapasitas RAM dan prosesor yang rendah.
\end{abstract}

Kata Kunci - Sistem Reservasi Hotel, JQuery Mobile, Hotel

\begin{abstract}
The amount of information that can be accessed online by using the mobile is not independent of the number system developed by the company in support of business activities. Hospitality is in Pontianak also provides a range of attractive facilities and also provides online messaging system. However, problems occurred when opening web pages created are not paying attention capacity of mobile devices, causing the screen size does not fit so many users feel uncomfortable. This study aims to generate information and reservation can be accessed by a variety of mobile devices regardless of the size of the mobile device. The system has been built to provide benefits and advantages mean because JQuery Mobile enables the system to run various mobile devices. Their JQuery Mobile, the developers do not need to design the user interface and encoding system from scratch because JQuery Mobile has a framework that is ready to be used and developed in accordance with the requirements of a system. Improvement and development needs to be done to ensure system flexibility towards all mobile devices, especially for the small screen size and has a RAM capacity and processor is low.
\end{abstract}

Keywords - Hotel Reservation System, JQuery Mobile, Hospitality 


\section{PENDAHULUAN}

Perkembangan teknologi informasi khususnya pada perangkat mobile (mobile device) telah banyak dipergunakan oleh masyarakat untuk mengakses informasi dengan mudah dan cepat. Banyaknya informasi yang dapat akses secara online dengan menggunakan mobile tidak terlepas dari banyaknya sistem informasi yang dikembangkan oleh setiap perusahaan dalam mendukung aktivitas bisnisnya. Layanan mobile tidak hanya terbatas pada melakukan transaksi tetapi juga memungkinkan komunikasi, kolaborasi dan koordinasi melalui perangkat mobile[1]. Di kota Pontianak Kalimantan Barat, sudah banyak hotel yang menyediakan berbagai fasilitas menarik yang dapat diakses secara online dan juga menyediakan sistem pesan kamar online. Namun yang menjadi permasalahan adalah ketika membuka halaman website yang dibuat tanpa memperhatikan kapasitas dari perangkat mobile, menyebabkan ukuran layar tidak cocok sama sekali dan itu menjadi penyebab banyaknya pengguna mobile yang merasa tidak nyaman[2] pada hal situs web hotel yang dikembangkan saat ini menjadi harapan untuk pemesanan kamar hotel secara online[3]. Jaringan nirkabel dan seluler telah mengalami pertumbuhan eksponensial dalam hal kemampuan perangkat mobile[4], namun untuk mengakses website yang besar dan desain yang kaku akan menjadi masalah dalam menampilkan konten dari website tersebut.

Aplikasi mobile memungkinkan pengguna untuk menggunakan teknologi informasi tanpa terikat ke satu lokasi, menyediakan pengguna dengan fleksibilitas, aksesibilitas dan kemudahan penggunaan[5] telah menjadikan perangkat mobile sebagai pilihan dalam mengakses informasi. Desain web responsif adalah salah satu tren terbaru yang dapat membantu dalam memenuhi harapan masyarakat. Tujuan dari desain web responsif adalah untuk membuat sebuah halaman web terlihat sama baik terlepas dari ukuran layar perangkat[6] dan hampir semua smartphone saat ini memiliki layar sentuh responsif yang membuat navigasi web lebih mudah[7]. Pesatnya pertumbuhan pengguna ponsel telah menciptakan banyak kesempatan untuk memanfaatkan jaringan seluler. Namun pengembangan aplikasi mobile masih menghadapi banyak tantangan, termasuk platform yang fragmentasi dan perubahan yang cepat dari teknologi mobile.

Untuk membangun sebuah web mobile yang terlihat dan berperilaku seperti aplikasi asli dan dapat secara otomatis bisa sesuai dengan berbagai resolusi dari perangkat, membutuhkan banyak pekerjaan jika mulai dari awal. Untuk mempercepat pengembangan, perlu didasarkan pada sebuah framework yaitu JQuery Mobile framework[8]. JQuery Mobile adalah JavaScript library's yang memungkinkan dan mendukung dalam mendesain berbagai macam perangkat smartphone untuk membuat terlihat dan berfungsi seperti aplikasi asli[9]. Kapasitas web mobile terus meningkat dengan pengenalan teknologi web baru, semakin banyak pengembang mencari framework untuk aplikasi mobile berbasis web (web apps) sebagai alternatif dalam menciptakan dan menyebarkan konten, tanpa perlu pengalaman code-based programming[10]. Dukungan mobile browser untuk fitur HTML5 merupakan faktor kunci dalam penyebaran teknologi dan upaya untuk mengadopsi dan mengintegrasikan standar[11]. HTML 5 mendukung teknologi mobile seperti geolocation dan location-based services (LBS), serta format terbuka yang lebih baru seperti scalable vector graphics. Pengembang demikian akan dapat mengembangkan halaman web tanpa perlu menguasai atau lisensi beberapa teknologi proprietary[12]. Mengacu kepada kondisi tersebut, maka dibutuhkan sebuah rancangan sistem reservasi hotel berbasis mobile di Kota Pontianak yang bertujuan untuk memberikan kemudahan bagi masyarakat untuk mendapatkan informasi hotel dan melakukan reservasi dengan perangkat mobile yang mereka memiliki.

\section{METODE PENELITIAN}

Penelitian berbentuk studi kasus dengan metode penelitiannya adalah Research and Development (R\&D). Metode pengembangan sistem reservasi hotel berbasis mobile mengimplementasikan metodologi AGILE dengan menerapkan model Rapid Application 
Development (RAD) dan alat pemodelan sistem adalah Unified Modeling Language (UML). Teknik pengumpulan data menggunakan wawancara, observasi dan mempelajari semua dokumen yang selama ini dipergunakan untuk melakukan aktivitas pengelolaan hotel. Tools yang penulis gunakan untuk melakukan pengujian sistem adalah Ripple Emulator. Ripple Emulator adalah sebuah multi platform emulator di lingkungan mobile yang dapat membantu menguji aplikasi web dengan menggunakan sejumlah perangkat yang berbeda dan resolusi layar yang berbeda juga.

\section{HASIL DAN PEMBAHASAN}

Sistem reservasi hotel berbasis mobile dibangun dengan memanfaatkan framework JQuery Mobile yang telah memberikan manfaat sangat berarti bagi pengembang sistem. Hal ini karena para pengembang sistem tidak perlu melakukan desain user interface dan pengkodean sistem dari awal karena JQuery Mobile memiliki framework yang siap dipergunakan dan dikembangkan sesuai dengan kebutuhan dari sebuah sistem. Sistem reservasi hotel berbasis mobile ini dapat dipergunakan oleh masyarakat untuk mendapatkan informasi hotel dimana saja dan kapan saja dengan menggunakan perangkat mobile yang dilengkapi dengan akses internet. Pemakaian sistem ini tidak mengharuskan pengguna melakukan instalasi sistem reservasi hotel pada perangkat mobile tersebut, akan tetapi pengguna hanya memerlukan web browser dan alamat website dari sistem reservasi tersebut. Software pendukung dalam menghasilkan sistem reservasi hotel adalah web server Apache, script PHP, HTML, JQuery Mobile Template dan database MySQL. Perancangan sistem reservasi hotel mengacu kepada metode perancangan perangkat Rapid Application Development (RAD). Perancangan arsitektur dari sistem reservasi hotel mempresentasikan framework dari sistem perangkat lunak yang dibangun seperti spesifikasi sistem dan interaksi subsistem. Arsitektur sistem reservasi hotel berbasis mobile dapat dilihat pada Gambar 1.

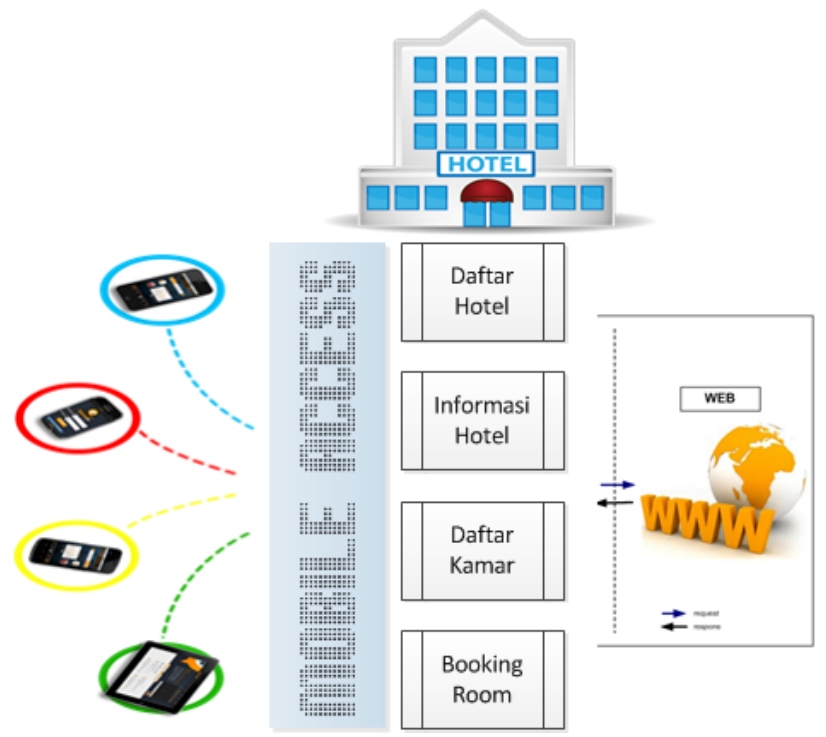

Gambar 1. Arsitektur Sistem Reservasi Hotel Berbasis Mobile

Perancangan sistem reservasi hotel berbasis mobile mengacu pada perancangan sistem berbasis obyek. Strategi ini dalam istilah aslinya disebut sebagai OOD (Object Orianted Design) dan dianggap menjadi startegi perancanaan paling modern saat ini. Dalam menghasilkan sistem reservasi hotel berbasis mobile, penulis menggunakan UML (Unified Modeling Language). Pemodelan use case diagram menjelaskan manfaat sistem jika dilihat menurut pandangan orang yang berada di luar sistem atau actor. Diagram ini menunjukkan fungsionalitas suatu sistem atau 
kelas dari bagaimana sistem berinteraksi dengan dunia luar. Perancangan use case diagram yang terjadi dalam sistem reservasi hotel berbasis mobile adalah sebagai berikut (lihat gambar 2).

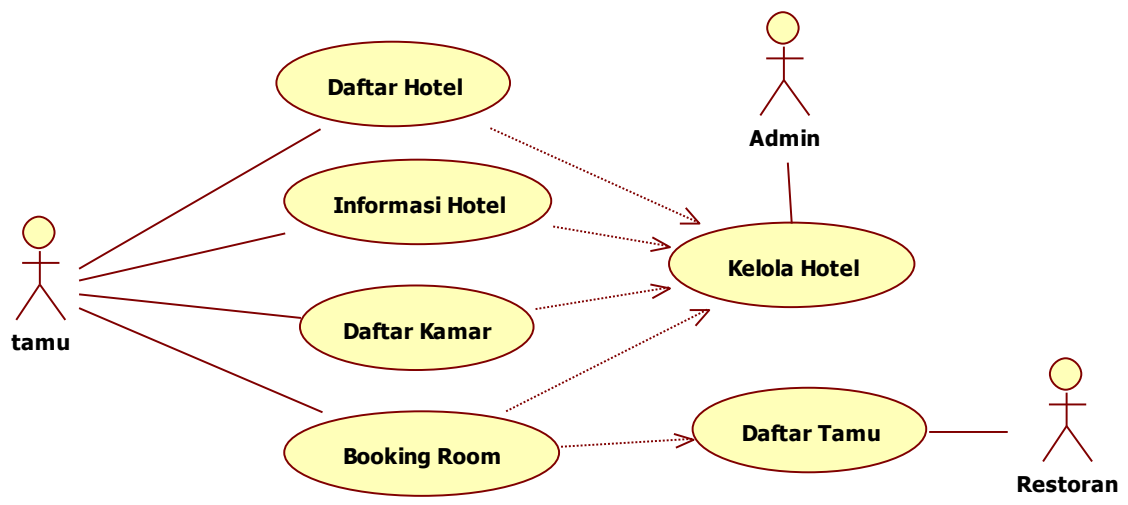

Gambar 2. Use Case Diagram Sistem Reservasi Hotel Berbasis Mobile

Activity diagram menggambarkan berbagai alur aktivitas dalam sistem yang sedang dirancang, bagaimana masing-masing alur berawal, decision yang mungkin terjadi dan bagaimana mereka berakhir. Activity diagram juga dapat menggambarkan proses paralel yang mungkin terjadi pada beberapa eksekusi. Activity diagram merupakan state diagram khusus, di mana sebagian besar state adalah action dan sebagian besar transisi di-trigger oleh selesainya state sebelumnya (internal processing). Oleh karena itu Activity diagram tidak menggambarkan behaviour internal sebuah sistem (dan interaksi antar subsistem) secara eksak, tetapi lebih menggambarkan proses-proses dan jalur-jalur aktivitas dari level atas secara umum. Sebelum tamu melakukan reservasi, tamu diharuskan untuk mengisikan data pribadi pada form registrasi. Berikut ini adalah activity diagram registrasi (lihat gambar 3):

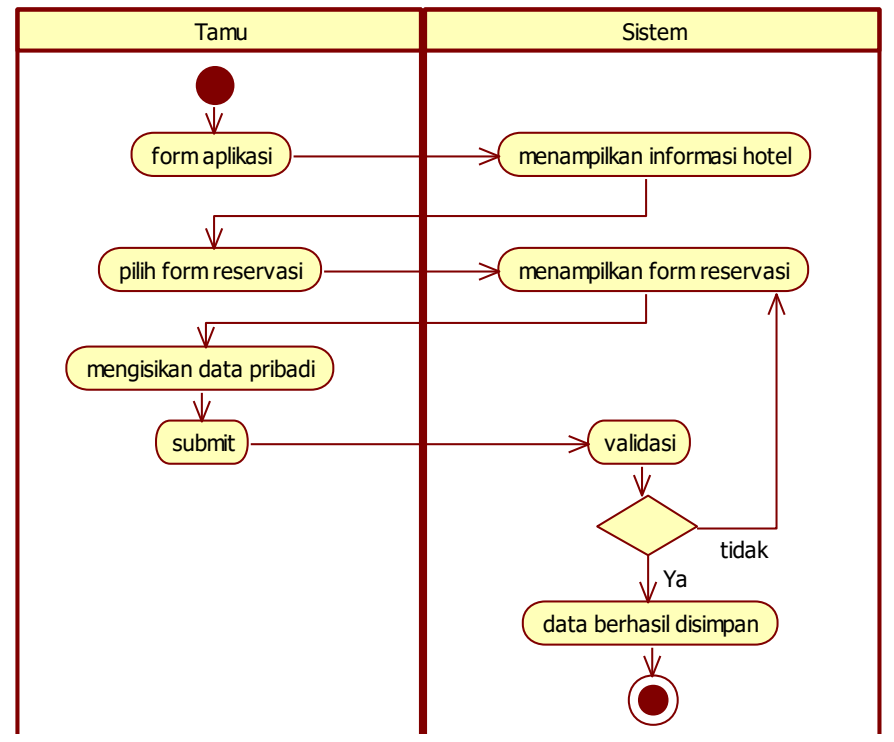

Gambar 3. Activity Diagram Registrasi Member

Activity diagram reservasi hotel menggambarkan aktivitas tamu dalam berinteraksi dengan sistem reservasi. Pada bagian ini tamu adalah sebagai pengendali utama dari form reservasi yaitu tamu melihat informasi dari hotel. Setelah melihat informasi dari kamar hotel, tamu mengisikan data tanggal cek in dan tanggal cek out yang diteruskan dengan mengisikan data pribadi yang melakukan reservasi. Data pribadi yang telah diisikan akan divalidasi oleh sistem dan jika data benar maka sistem akan menyimpan data dan jika data tidak benar, maka sistem akan mengembalikan ke form reservasi. 


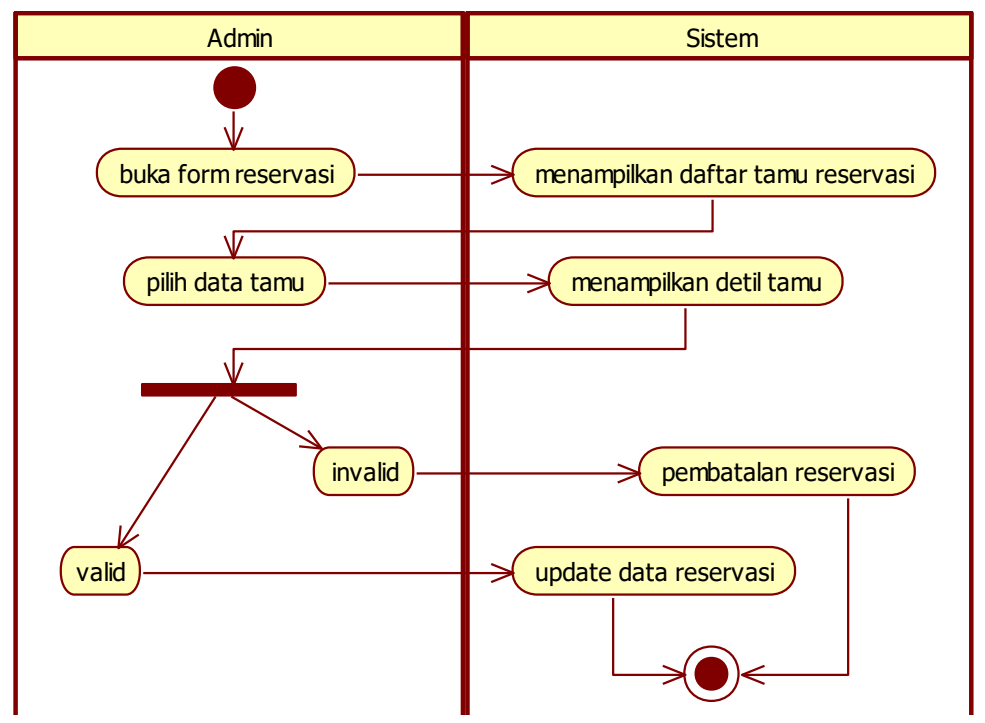

Gambar 4. Activity Diagram Submit Reservasi

Activity diagram submit reservasi (lihat gambar 4) memberikan penjelasan bagaimana aktivitas seorang admin dalam melakukan pengecekan terhadap data tamu yang telah melakukan reservasi. Admin dapat melihat data tamu yang telah melakukan reservasi dan kemudian admin dapat men-submit data jika datanya sesuai dan admin dapat membatalkan reservasi jika data tidak sesuai. Setelah data berhasil disubmit, maka sistem akan melakukan update terhadap data reservasi.

Diawali dari apa yang men-trigger aktivitas tersebut, proses dan perubahan apa saja yang terjadi secara internal dan output apa yang dihasilkan. Masing-masing objek, termasuk aktor, memiliki lifeline vertikal. Message digambarkan sebagai garis berpanah dari satu objek ke objek lainnya. Pada fase desain berikutnya, message akan dipetakan menjadi operasi/metoda dari class. Pengembangan sistem reservasi hotel berbasis mobile memiliki 2 (dua) buah model sequence diagram yaitu sequence reservasi dan sequence diagram submit reservasi.

\section{Sequence Diagram Reservasi}

Sequence diagram reservasi memperlihatkan bagaimana seorang tamu berinteraksi langsung dengan sistem. Ketika tamu melakukan membuka aplikasi, maka sistem akan menampilkan informasi hotel sesuai dengan hotel yang dipilih. Pada hotel yang telah dipilih, tamu dapat melakukan pengisian data pribadi sesuai dengan item yang ada pada form reservasi. Data pribadi yang telah diisi akan dilakukan validasi oleh sistem untuk memastikan data diisi dengan benar. Jika data benar maka sistem akan menampilkan data berhasil disimpan. Berikut ini adalah gambar sequence diagram reservasi (lihat gambar 5): 
Citec Journal, Vol. 3, No. 1, November 2015 - Januari 2016

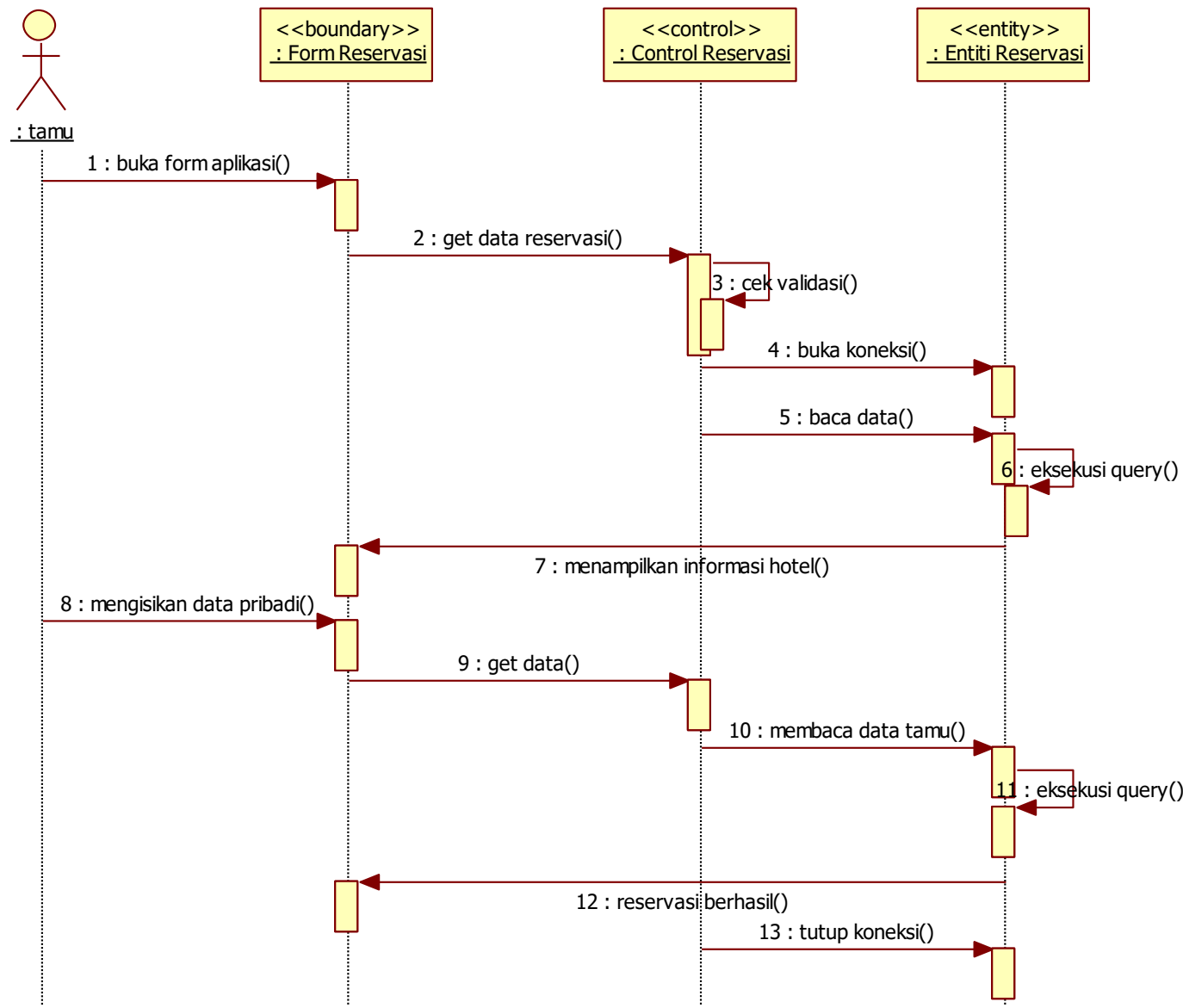

Gambar 5. Sequence Diagram Reservasi

2. Sequence Diagram Submit Reservasi

Sequence diagram submit reservasi memperlihatkan bagaimana seorang admin berinteraksi langsung dengan sistem. Ketika admin melakukan form reservasi, maka sistem akan menampilkan data tamu yang telah melakukan reservasi. Dari data tersebut, admin akan melakukan pengecekan untuk memastikan data tamu benar. Setelah data dipastikan benar, maka admin akan memproses data tersebut dengan melakukan submit. Setelah data disubmit, maka sistem akan meng-update data reservasi tersebut. Berikut ini adalah gambar sequence diagram submit reservasi (lihat gambar 6): 


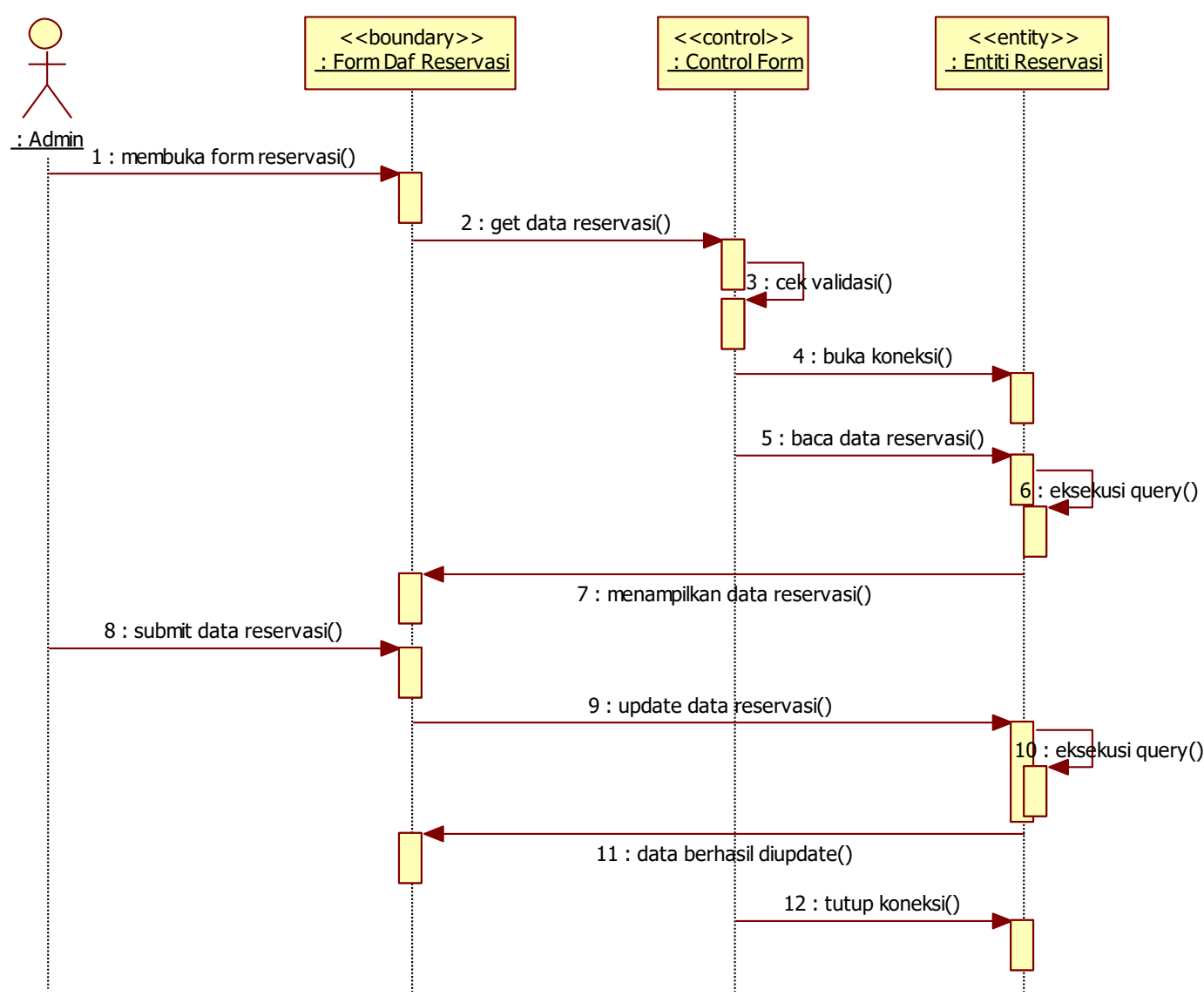

Gambar 6. Sequence Diagram Submit Reservasi

Perancangan rinci (detailed design) menentukan modul program (prosedural) yang harus dibuat. Dari sudut pandang teknis kegiatan perancangan terdiri atas aktivitas perancangan database, perancangan interface dan perancangan navigasi. Pokok pemikiran dalam merancang database adalah bagaimana merancang database sehingga dapat memenuhi kebutuhan saat ini dan kemudahannya untuk dikembangkan dimasa yang akan datang. Perancangan model konseptual perlu dilakukan disamping perancangan secara phisik. Pada perancangan konseptual, digunakan beberapa konsep pendekatan relasional namun tidak berarti konsep ini harus diimplementasikan ke model relasional saja tetapi juga dapat dengan model Hirarchi dan model Network. Model konseptual mengkombinasikan beberapa cara untuk memproses data dan untuk beberapa aplikasi. Model konseptual tidak tergantung aplikasi tertentu dan tidak tergantung Database Management System (DBMS) dan hardware yang digunakan. Pada perancangan model konseptual tinjauan dilakukan pada struktur data dan relasi antar file menggunakan model dan relasional. Kamus data merupakan suatu penjelasan secara tertulis mengenai data yang terorganisir tentang komposisi dari pada elemen proses data, arus data dan simpanan data yang terdapat pada pemodelan diagram atus data secara logika. Sehubungan dengan perancangan sistem reservasi hotel berbasis mobile yang difokuskan pada rancangan sistem usulan ini maka akan dilakukan pembuatan kamus data. Kamus data digunakan untuk membantu para pemakai mengerti mengenai aplikasi yang akan dikembangkan secara terinci dan mengorganisasikan semua elemen data yang terkait serta tidak mengalami kesulitan dalam memahami pemodelan sistem yang dikembangkan secara logika. Adapun simpanan data yang digunakan dalam sistem usulan antara lain meliputi:

tamu $=$ @ idtamu + namadepan + namabelakang + email + telpon + warganegara

tipekamar $\quad=$ @ kodetipe + namatipe + tarif

room $=$ = nomorkamar $+@ @$ kodetipe + bed + status + max

reservasi $=$ tglcheckin + tglcheckout + jlhorang $+@ @$ idtamu $+@ @$ nomorkamar + tarif

office $\quad=@$ kodeob + namaob + alamatob $+\mathrm{hp}$ 
officeroom = @ @kodeob + @ @ kodetipe

fotoroom $=@ @$ kodetipe + foto

Table tamu terdiri dari satu field yang berlaku sebagai primary key yaitu idtamu yang merupakan nomor unik yang dimiliki oleh setiap tamu. Table tipekamar terdiri dari satu field yang berlaku sebagai primary key yaitu kodetipe yang merupakan nomor unik yang dimiliki oleh setiap tipe kamar. Table room terdiri dari satu field yang berlaku sebagai primary key yaitu nomorkamar dan satu field yang berlaku sebagai foreign key yaitu kodetipe. tipekamar yang ada di dalam table room sebagai penghubung ke table tipekamar, dimana pada kasus ini table tipekamar sebagai table referensi dari table room. Table reservasi terdiri dari dua field yang berlaku sebagai foreign key yaitu idtamu dan nomorkamar. idtamu yang ada di dalam table reservasi sebagai penghubung ke table tamu, dimana pada kasus ini table tamu sebagai table referensi dari table reservasi. Sedangkan field nomorkamar dipergunakan untuk penghubung antara table reservasi dengan table room dimana table room dijadikan sebagai table referensi untuk table reservasi. Table office terdiri dari satu field yang berlaku sebagai primary key yaitu kodeob. Tabel officeroom terdiri dari dua field yang berlaku sebagai foreign key yaitu kodeob dan kodetipe. Field kodeob dipergunakan untuk menghubungkan tabel officeroom dengan tabel office boy sedangkan field kodetipe dipergunakan untuk menghubungkan tabel officeroom dengan dengan tipe kamar. Tabel fotoroom terdiri dari satu field yang berlaku sebagai foreign key yaitu kodetipe dimana field ini dipergunakan untuk menghubungkan tabel fotoroom dengan tabel tipekamar.

Diagram hubungan entitas adalah suatu dokumentasi data dengan mengidentifikasi entiti data dan memperhatikan hubungan yang ada diantara entiti tersebut. Dalam hal ini, penulis menggunakan permodelan diagram hubungan entitas ini untuk menggambarkan hubungan antar simpanan data di dalam rancangan sistem yang diusulkan. Adapun relasi-relasi yang ada dalam diagram tersebut dapat dilihat dalam diagram berikut ini (lihat gambar 7):

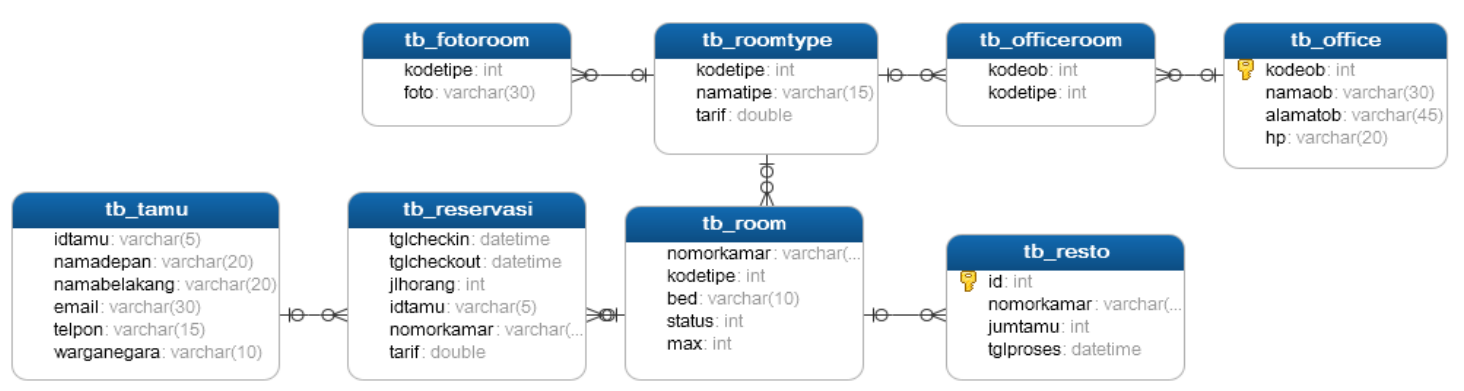

Gambar 7. Diagram Hubungan Entitas Sistem Reservasi Hotel Berbasis Mobile

Gambar diagram hubungan entitas dapat dijelaskan secara singkat bahwa setiap setiap tamu bisa melakukan beberapa kali reservasi. Satu kamar bisa direservasi beberapa kali oleh tamu dan satu tipe kamar bisa terdiri dari satu atau beberapa kamar. Selanjutnya dalam merancang antarmuka merupakan bagian yang paling penting dari merancang sistem. Biasanya hal tersebut juga merupakan bagian yang paling sulit karena dalam merancang antarmuka harus memenuhi tiga persyaratan sebuah antarmuka yaitu sederhana, lengkap, dan harus memilki kinerja yang cepat. Alasan utama mengapa antarmuka sulit untuk dirancang adalah karena setiap antarmuka adalah sebuah bahasa pemrograman yang kecil. Antarmuka menjelaskan sekumpulan objek-objek dan operasi-operasi yang bisa digunakan.

\section{Antarmuka Informasi Hotel}

Antarmuka informasi hotel (lihat gambar 8) dipergunakan untuk menampilkan daftar nama hotel yang sudah masuk ke dalam database. Antaramuka ini penting bagi setiap tamu dalam menentukan pilihan terhadap hotel yang diinginkan. Tamu dapat mencari dengan mengetikkan 
nama hotel atau dengan cara menggeser layar ke bawah. Berikut ini adalah tampilan antarmuka informasi kamar:
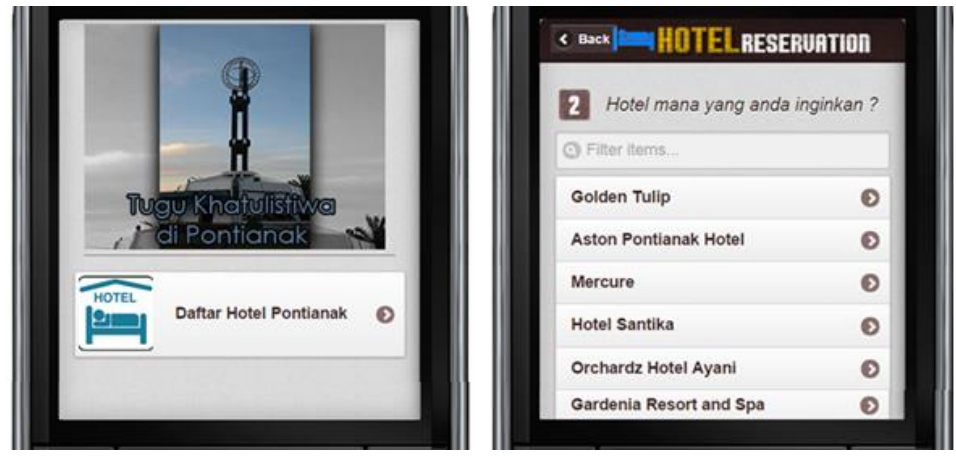

Gambar 8. Form Antarmuka Informasi Hotel

2. Antarmuka Tipe Kamar

Antarmuka tipe kamar (lihat gambar 9) dipergunakan untuk menampilkan daftar tipe kamar sesuai dengan hotel yang telah dipilih oleh tamu. Antarmuka ini penting bagi setiap tamu dalam menentukan pilihan terhadap tipe kamar yang diinginkan. Tamu dapat menggeser layar ke bawah sebelum menentukan pilihan tipe kamar. Berikut ini adalah tampilan antarmuka tipe kamar hotel:
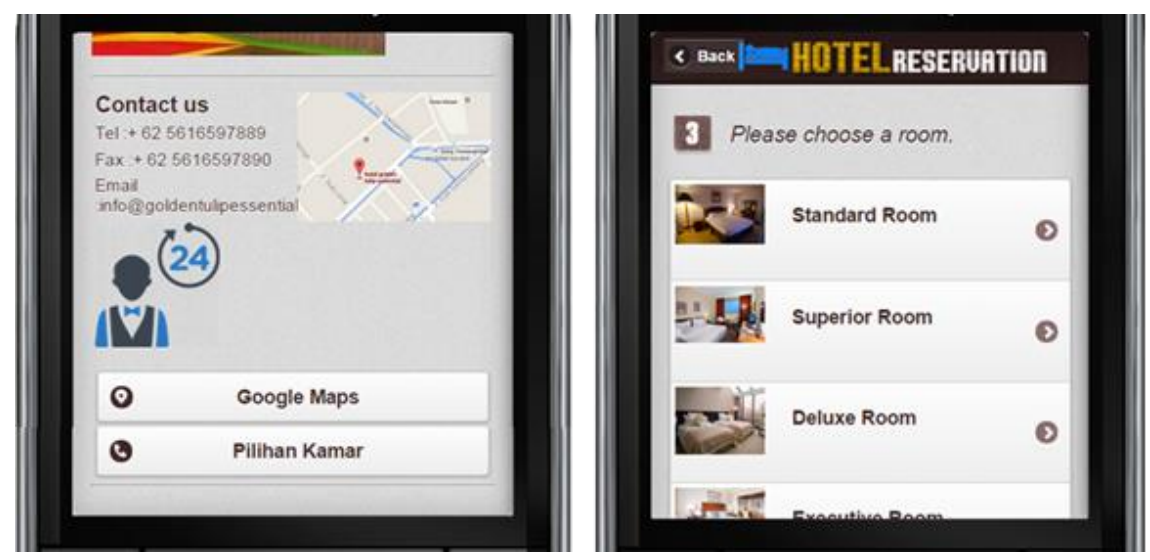

Gambar 9. Form Antarmuka Tipe Kamar

\section{Antarmuka Pengisian Data Pribadi}

Antarmuka form pengisian data pribadi (lihat gambar 10) dipergunakan oleh tamu untuk mengisikan data pribadi yang melakukan pemesanan terhadap kamar. Form ini tampil setelah tamu memilih tipe kamar dan setelah mengisikan tanggal check in dan tanggal check out. Data yang telah diisikan dan disubmit akan masuk ke dalam database dan dapat langsung dilihat oleh admin web. Berikut ini adalah tampilan antarmuka pengisian data pribadi: 

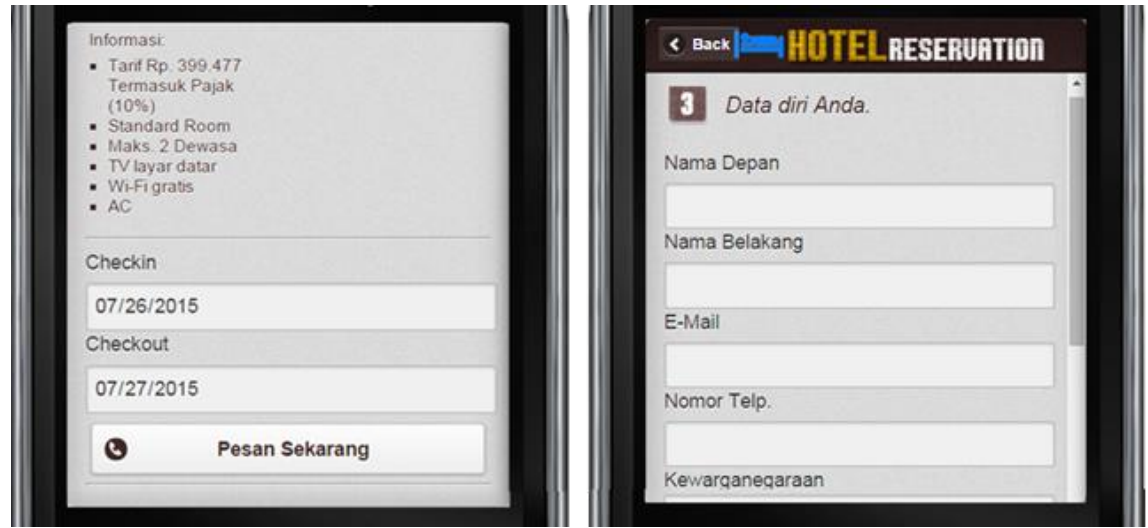

Gambar 10. Form Antarmuka Pengisian Data Pribadi

\section{KESIMPULAN}

Setelah melakukan perancangan sistem reservasi hotel dengan framework JQuery Mobile dan dilakukannya percobaan beberapa kali, maka dapat disimpulkan bahwa sistem reservasi hotel berbasis mobile yang dibangun dengan memanfaatkan framework JQuery Mobile telah memberikan manfaat dan keuntungan sangat berarti bagi pengembang sistem. Dengan adanya framework JQuery Mobile, para pengembang tidak perlu melakukan desain user interface dan pengkodean sistem dari awal karena JQuery Mobile memiliki framework yang siap dipergunakan dan dikembangkan sesuai dengan kebutuhan dari sebuah sistem. Para pengembang hanya perlu menguasai bahasa pemrograman PHP dan database MySQL untuk melakukan pengolahan data tamu dan reservasi agar informasi yang ditampilkan bersifat dinamis. Kebutuhan untuk pemakaian sistem ini hanya memerlukan web browser dan alamat website dari sistem reservasi tersebut dan pengguna tidak perlu melakukan instalasi sistem reservasi hotel pada perangkat mobile mereka. Sistem reservasi hotel berbasis mobile ini dapat berjalan pada smartphone dengan menggunakan browser add-on dari OS mobile.

\section{SARAN}

Pengembangan sistem reservasi hotel berbasis mobile dengan memanfaatkan framework JQuery Mobile memang bisa berjalan dengan baik pada setiap perangkat mobile. Namun ada beberapa perangkat mobile yang memiliki kapasitas proses lebih rendah baik itu RAM maupun prosesornya mengalami kendala dalam menampilkan halaman web. Perangkat mobile yang tidak bisa menampilkan layar dalam bentuk landscape juga memiliki keterbatasan dalam menampilkan informasi yang panjang. Oleh karena itu, maka dalam penelitian berikutnya, sistem reservasi hotel berbasis mobile dapat memanfaatkan Bootstrap karena bootstrap front-end framework yang mengedepankan tampilan untuk mobile device (Handphone, smartphone dll).

\section{UCAPAN TERIMA KASIH}

Penulis mengucapkan terima kasih kepada Sekolah Tinggi Manajemen Informatika dan Komputer (STMIK) Pontianak yang telah memberikan dukungan finansial terhadap penelitian ini. Terima kasih kepada rekan-rekan dosen yang telah memberikan masukan dan dukungan dalam menyelesaikan tulisan ini. Kepada para reviewer saya juga mengucapkan banyak terima kasih atas bimbingan dan arahannya sehingga tulisan ini dapat sesuai seperti apa yang diharapkan. Semoga tulisan ini dapat memberikan manfaat bagi banyak orang, saat ini maupun yang akan datang. 


\section{DAFTAR PUSTAKA}

[1] Olaniyi, O. M., Ajose, S. O., Adegoke, M. A., 2010, Development of a mobile airline reservation and payment system, International Journal of Electronic Finance, No. 4, Vol. 4, Hal. 372-389.

[2] Lee, K., 2013, Implementation of Smartphone System using QR Code in Mobile Environment, International Journal of Software Engineering and Its Applications, No. 7, Vol. 6, Hal. 137-146.

[3] Stringam, B. B., Gerdes Jr. J., 2010, Are pictures worth a thousand room nights? Success factors for hotel web site design, Journal of Hospitality and Tourism Technology, No. 1, Vol. 1, Hal. 30-49.

[4] Varshney, U., Vetter, R., 2002, Mobile commerce: framework, applications and networking support, Mobile networks and Applications, No. 3, Vol. 7, Hal. 185-198.

[5] Alfawaer, Z. M., Awni, M., Al-Zoubi, S., 2011, Mobile e-ticketing reservation system for Amman International Stadium in Jordan, International Journal of Academic Research, No. 1, Vol. 3, Hal. 848-852.

[6] Kim, B., 2013, Responsive web design, discoverability, and mobile challenge., Library Technology Reports, No. 6, Vol. 49, Hal. 29-39.

[7] Jones, R. G., 2011, Emerging technologies: Mobile apps for language learning, Language Learning \& Technology, No. 2 , Vol. 15, Hal. 2-11.

[8] Mao, X., Xin, J., 2014, Developing Cross-platform Mobile and Web Apps, CIGR Proceedings : World Conference on Computers in Agriculture and Natural Resources, University of Costa Rica, San Jose Costa Rica, 27 - 30 Juli 2014.

[9] Jobe, W., 2013, Native Apps Vs. Mobile Web Apps, International Journal Of Interactive Mobile Technologies, No. 4, Hal. 7, Hal. 27-32.

[10] Sin, D., Lawson, E., Kannoorpatti, K., 2012, Mobile Web Apps - The Non-programmer's Alternative to Native Applications, in 2012 5th International Conference on Human System Interactions (HSI), Perth, West Australia, 6 - 8 Juni 2012.

[11] Juntunen, A., Jalonen, E., Luukkainen, S., 2013, HTML 5 in Mobile Devices - Drivers and Restraints, in 2013 46 ${ }^{\text {th }}$ Hawaii International Conference on System Sciences (HICSS), Grand Wailea, Maui, Hawaii, 7 - 10 Januari 2013.

[12] Nichols, S. J. V., 2010, Will HTML 5 Restandardize the Web?, Computer, No. 4, Vol. 43, Hal. 13-15. 